\title{
Convincing State-Builders? Disaggregating Internal Legitimacy in Abkhazia ${ }^{1}$
}

\author{
Kristin M. BAKKe \\ University College London \\ John O'LOughlin \\ University of Colorado \\ GERARD TOAL \\ Virginia Tech \\ AND \\ MichaEL D. WARD \\ Duke University
}

\begin{abstract}
De facto states, functional on the ground but unrecognized by most states, have long been black boxes for systematic empirical research. This study investigates de facto states' internal legitimacy-people's confidence in the entity itself, the regime, and institutions. While internal legitimacy is important for any state, it is particularly important for de facto states, whose lack of external legitimacy has made internal legitimacy integral to their quest for recognition. We propose that the internal legitimacy of de facto states depends on how convincing they are to their "citizens" as state-builders. Using original data from a 2010 survey in Abkhazia, we examine this argument based on respondent perceptions of security, welfare, and democracy. Our findings suggest that internal legitimacy is shaped by the key Weberian state-building function of monopoly of the legitimate use of force, as well as these entities' ability to fulfill other aspects of the social contract.
\end{abstract}

We are not a failed state, but we are building a normal state. Despite the war, we survived and are building a state despite no help from the outside, in fact, in the face of opposition from the outside.

\section{—Manana Gurgulia, Director of Apsny Press, the state press agency of Abkhazia. ${ }^{2}$}

In most separatist conflicts, where nonstate groups fight for independence or greater autonomy within a state's border, the outcome entails no major change to state boundaries. The separatists are either defeated or appeased with some form of institutional solution short of independence, such as decentralized governance or various autonomy arrangements. Yet in some cases, the conflict results in the creation of so-called de facto states. Referred to as breakaway regions by their parent states, most de facto states aspire to be fully independent states and express this in formalized declarations of independence. While they possess domestic or "internal sovereignty," in that they control and administer most or all of the territory they claim, most de facto states fail to

${ }^{1}$ Authors' notes: This survey work and fieldwork were supported by the US National Science Foundation (Grant Number HSD 0827016), with additional support from the Economic and Social Research Council in the UK (grant number RES-000-22-4507). We want to thank the Levada Center, Moscow and Krasnodar, for implementation of the survey, as well as the many officials and NGO members that we interviewed in Abkhazia. Replication data are available from the IQSS Dataverse Network.

${ }^{2}$ Personal communication, Sokhumi (Sukhum), November 9, 2009. acquire international legitimacy as states; rather, they become unrecognized states, entities denied international legal sovereignty, sometimes termed "external sovereignty," by the existing community of states. De facto states, in sum, are transgressive territorial entities that look and function like states but are not recognized as such. ${ }^{3}$ In this article, we use the case of Abkhazia to consider how de facto state-building efforts shape internal perceptions of legitimacy.

The post-Cold War era has seen a proliferation of de facto states, most of them born out of violent struggles with their parent states. The collapse of the Soviet Union and armed conflicts in Russia, Azerbaijan, Georgia, and Moldova were followed by the emergence of a number of such "statelets"-Chechnya, Nagorno Karabakh, Abkhazia, South Ossetia, and Transnistria-but de facto states exist also in other parts of the world and have been features on the international scene for decades (think of Northern Cyprus and Taiwan). At least 21 de facto states have been created since World War II (Caspersen and Stansfield 2010:4). ${ }^{4}$ More than half of these entities have ceased to exist as de facto states and either been recaptured by their parent state or, in a few cases, received international recognition as states, but many also endure

\footnotetext{
${ }^{3}$ For definitional discussions, see Pegg (1999), Anderson (2010:184-187), Caspersen and Stansfield (2010:3-4), and Mampilly (2011:25-48).

${ }^{4}$ Caspersen and Stansfield's (2010) list includes Abkhazia, Anjouan, Biafra, Bougainville, Chechnya, East Timor, Eritrea, Gagauzia, Katanga, Kosovo, Kurdistan-Iraq, Montenegro, Nagorno Karabakh, Northern Cyprus, Republika Srpska, Republika Srpska Krajina, Somaliland, South Ossetia, Taiwan, Tamil Eelam, and Transnistria.
} 
TABle 1. Post-Soviet de facto States Born Out of Violent Struggles

\begin{tabular}{|c|c|c|c|c|c|}
\hline $\begin{array}{l}\text { Separatist } \\
\text { Group(s) }\end{array}$ & Parent State & $\begin{array}{c}\text { Violent } \\
\text { Conflict Begins }\end{array}$ & $\begin{array}{l}\text { Ceasefire/Birth of } \\
\text { de facto State }\end{array}$ & De facto State & Endurance \\
\hline $\begin{array}{l}\text { Armenians/ } \\
\text { Karabakhis }\end{array}$ & $\begin{array}{l}\text { USSR/ } \\
\text { Azerbaijan }\end{array}$ & 1988 & 1994 & Nagorno Karabakh & Still existing \\
\hline Dniester Slavs & Moldova & 1990 & 1992 & Transnistria & Still existing \\
\hline Chechens & $\begin{array}{l}\text { Russian } \\
\text { Federation }\end{array}$ & 1994 & 1996 & $\begin{array}{l}\text { Chechen Republic } \\
\text { of Ichkeria }\end{array}$ & Recaptured by Russia in 1999 \\
\hline Ossetians & Georgia & 1991 & 1992 & South Ossetia & Both still existing but separation \\
\hline Abkhaz & Georgia & 1992 & 1993 & Abkhazia & challenged in 2008 war with Georgia \\
\hline
\end{tabular}

for years on end, despite their lack of international recognition. One factor possibly accounting for the endurance of de facto states concerns how legitimate they are internally, in the eyes of their inhabitants. Indeed, while internal legitimacy-people's confidence and belief in the entity itself, the ruling regime, and state institutions-is important for any state, it is particularly important for unrecognized states, whose lack of external legitimacy has made claims to internal legitimacy integral to their quest for recognition (Caspersen 2008). Yet to date, we have relatively little systematic knowledge of what populations in de facto states think about these entities and their rulers. This article begins to address this absence by conceptualizing what internal legitimacy means, theorizing how it comes about, and empirically examining its sources. Using original data from a survey we organized in Abkhazia in 2010, we systematically explore the conditions that facilitate internal legitimacy in a postwar de facto state. Our argument focuses on how convincing these entities are as state-builders, particularly their ability to provide for their citizens' material and physical security.

\section{Internal Legitimacy}

While researchers have long addressed why civil wars and separatist struggles emerge, we have less systematic knowledge about how postwar societies fare after the fighting officially ends (Barakat 2005). In many cases, the postwar era is far from peaceful. Peace settlements are assumed to bring an end to the war but are sometimes followed by high levels of criminal violence, civilian victimization, or political violence among former enemies, even among former allies (for example, Atlas and Licklider 1999; Autesserre 2009; Boyle 2009). De facto states are a peculiar and fragile form of postwar societies, given that their status remains undecided. While not all de facto states are born out of violent struggles, most are, as states are generally reluctant to cede control over territory. ${ }^{5}$ In the de facto states in the post-Soviet world, the violent conflicts from which these entities emerged have not formally come to an end through peace agreements but rather military victories followed by ceasefires. ${ }^{6}$ While Nagorno Karabakh, Abkhazia, South Ossetia, and Transnistria so far have survived as state-like entities in the international system, Georgia tried to reinstate its control over both Abkhazia and South Ossetia in the August 2008 war. Chechnya, in contrast, had a relatively short life as a de

\footnotetext{
${ }^{5}$ Entities with de facto state authority are not necessarily born out of separatist struggles (Mampilly 2011:50-58), but many are.

${ }^{6}$ A ceasefire is a settlement wherein the warring parties agree to lay down their weapons; in a peace agreement, the warring parties agree also on steps toward a political solution.
}

facto state from 1996 until 1999, when it was recaptured by Russia (Table 1).

The most typical death for a de facto state is recapture or reintegration by its parent state, as happened with Republika Krajina in Croatia in 1995, although they can also cease to exist as unrecognized entities by gaining recognition, as in the case of East Timor (de facto state within Indonesia 1999-2002) and Eritrea (de facto state within Ethiopia 1991-1993). ${ }^{7}$ Kosovo represents a contested case of partial recognition, now recognized by more than 90 UN member states. Abkhazia and South Ossetia were unilaterally recognized by Russia after the August 2008 war, with only Nicaragua, Venezuela, and a few small island states following their lead. For the vast majority of the international community, they remain unrecognized de facto states.

Despite their lack of international recognition, de facto states sometimes endure thanks to the benefits that their elites reap from positions of power and illicit economies (King 2001; Lynch 2004), the relative weakness of their parent states (Kolstø 2006), or external support (Lynch 2004; Kolstø 2006; Stanislawski 2008; Anderson 2010; Mulaj 2010). De facto states, like states, can also endure due to internal legitimacy, people's acceptance and loyalty to the ruling authority. Our aim in this article is not to examine the causal link from internal legitimacy to endurance, which is an important question in its own right. Rather, we examine an important foundational question: What are the local perceptual factors that shape internal legitimacy in de facto states? While researchers have begun to measure internal legitimacy in de facto states (Berg 2012; Berg and Mölder 2012), there is need for conceptual debate about what internal legitimacy means, as well as theoretical thought about the perceptual variables shaping it.

Conceptually, we think of legitimate political authority as one that fosters, among its subjects, an obligation to obey or comply with its rules, predominantly through consent. Lake argues that "Obligation arises from the collective's belief in rightful rule" (2010:31). Empirically, we capture legitimacy by examining "the ruled's" perceptions: their belief in and sense of loyalty to "the ruler." We treat internal legitimacy as a concept that has distinctive and discrete dimensions: state legitimacy, regime legitimacy, and institutional legitimacy.

State legitimacy means that the population within a state accepts the state's myths and rules of the game (Migdal 1988:32-33). Indeed, Migdal argues that key to any state's survival is that citizens do not question its presence; that there is a "shared sense that the state is as

\footnotetext{
${ }^{7}$ On why the international community recognizes only some states, see
} Seymour (2012). 
natural as the rivers and the mountains" (2001:168). Thus, state legitimacy is about believing in the state and its right to exist; it is about the population's adherence to the foundational myth of a political entity as a state. The greater the unquestioned naturalization of a political order as a state, the greater its state legitimacy. In the case of de facto states, we can, empirically, think of state legitimacy as people's belief in the entity's existence as independent from its parent state-an acceptance of its foundational myth. ${ }^{8}$ Regime legitimacy is not about the state per se but about the state's regime; it is about trusting the people in power. One can imagine that despite believing in a state's right to exist, you might not approve of the people in power, thus scoring high on state legitimacy but low in regime legitimacy. Indeed, this is a common condition in the United States, where "loving the country but hating the government" is the preferred position of many so-called Tea Party patriots. Finally, while regime legitimacy is about people's belief in the people in power, such as the president and parliament, one can also think of legitimacy as people's perceptions of state institutions in themselves, such as the police or judiciary (Norris 1999:221-22; Seligson 2002). We refer to this as institutional legitimacy. In sum, our disaggregation of legitimacy distinguishes between state myths, people in power, and functional bureaucracy.

\section{Sources of Internal Legitimacy: De facto States as Convincing State-Builders}

We begin with the contention that internal legitimacy is a result of how convincing de facto states are as state-builders. Legitimate authority rests with an implicit (and often mythologized) social contract between ruler and ruled: The ruler provides benefits, most importantly social order, to the ruled, and the ruled, in turn, accept the ruler's right to rule (see Moore 1978:20-25). That is, people's perceptions of how good de facto states are at doing the things that states do will shape their belief in the entity's right to exist as an independent entity, their acceptance of its regime, and their trust in its political institutions. ${ }^{9}$ Armed groups sometimes engage in wartime governance activities, such as establishing territorial control, protecting civilians, or providing public goods (for example, McColl 1969; Wickham-Crowley 1987; Wood 2003; Kasfir 2005; Mampilly 2011). Besides providing physical protection, providing public goods such as schools and healthcare can be critical for insurgents' ability to enforce their legitimacy and reduce the chances that the civilian population turns against them. Building on these insights, we propose that internal legitimacy in de facto states born out of violent struggles depends on whether they are able to provide their inhabitants with democratic participation, economic goods, and security. Indeed, given the importance of security in the social contract between ruler and ruled (Lake 2010), as well as the centrality of the monopoly on the legitimate use of force to what it means to be a state (Weber 1958), an ability to ensure their citizens' security, both from external enemies and domestic instability, is key for de facto

\footnotetext{
${ }^{8}$ In separatist struggles, the goal can be the creation of an independent state, but it can also be irredentist, in the sense that the goal is unification with a different state than the parent state.

${ }^{9}$ There is a mutually reinforcing relationship here, in the sense that legitimacy, in turn, aids state-building efforts (Lake 2010). For example, it is easier for a state to collect taxes (to fund public goods) if it is seen as legitimate.
}

states' internal legitimacy. An important prior, but separate, research question is why some de facto states (or insurgents or states) are better state-builders than others (Mampilly 2011), which in the context of Abkhazia cannot be seen in isolation from Russia's external support, both financially and militarily (Kolossov and O'Loughlin 2011). Here, our focus is on how the population's perceptions of state-building efforts shape their view of the state, the regime, and institutions.

Let us first turn to democracy. Democracy, in its idealistic normative form, as a variable shaping legitimacy is consistent with the Weberian notion of rational-legal legitimacy, where legitimacy comes from public processes that create accountability (Weber 1978). We can also think of democracy as a public good that the ruling authority grants the citizens. Research has found democratic practices to boost people's confidence in regimes and political institutions (Norris 1999). It is reasonable to expect people's perceptions of functioning democratic procedures to be a particularly important source for internal legitimacy in states and state-like entities emerging out of violent conflict and authoritarian settings (Mishler and Rose 2001), as in the post-Soviet de facto states. Indeed, while de facto states often make claims for international recognition based on the principle of selfdetermination, some, including Abkhazia, also claim that they deserve to become sovereign states because they have proven that they are viable democracies (Caspersen 2008); while they may not have external legitimacy, they maintain that they have, based on their democratic credentials, internal legitimacy. Thus, we expect people's perceptions of functioning democratic practices to boost state, regime, and institutional legitimacy.

Internal legitimacy can also rest with states and political leaders' ability to provide citizens with material security and economic public goods, such as employment and welfare (Scott 1972; Moore 1978; Gilley 2006; OECD 2010). Rebels sometimes go to great lengths to provide public goods in the territories they control (Mampilly 2011), with consequences for their ability to rule (Wickham-Crowley 1987). We expect the same to hold for de facto states. Schlichte argues that the ability to organize and finance public services is important for the legitimacy of armed groups that have conquered an area in the sense that people see that "the new power is not only able to kill and to destroy but to build and invest as well" (2009:96). One would imagine concerns about economic public goods provision to be particularly important for people living in de facto states if they perceive that they are worse off in comparison with the parent state.

We emphasize that an important source for internal legitimacy is security for a state or de facto state's inhabitants. Indeed, if a de facto state is characterized by violence and insecurity, internal legitimacy is likely to suffer both directly and indirectly (see OECD 2010; Bakke 2011). Directly, de facto states unable to provide for their citizens' security (and their possessions and property) may be less likely to be perceived as legitimate than peaceful ones (see Schlichte 2009), as providing security is key to what it means to be a state. Indeed, in Tilly's (1985) classic formulation, part of what turns war-making into state-making is a state's ability to protect its supporters. In the context of "guerrilla governments" in Latin America, Wickham-Crowley (1987:478) has argued that armed groups establish authority by fulfilling the classic functions associated with government, thus forming a social contract with the population. Similarly, providing 
people with social order-protection from internal and external dangers - is particularly important to establishing a sense of legitimate authority in a postwar society (Lake 2010). In the context of de facto states, not only do the authorities have to convince the population that they can do more than fight the parent state; they have to also convince the population that they can provide for their security just as well, or even better, than the parent state.

Indirectly, continued violence in a postwar society may jeopardize public goods provision, in turn diminishing internal legitimacy. If the postwar era is characterized by empowered warlords, mafias, violence, crime, or corruption, public goods provision may suffer as tax revenues decline, and rulers may spend resources on attracting support from loyal "strongmen" rather than providing public goods (Reno 2002). Moreover, postwar societies face material destruction and disrupted or diminished economic growth (for example, Collier 2009; Kang and Meernik 2009). These problems are likely to be aggravated by low foreign investments. For investors, de facto states may represent a legal vacuum and be undesirable places to invest (although in the case of Abkhazia, there are active efforts at trying to attract FDI by providing information and assistance). As such, postwar violence in de facto states may be damaging for economic growth and, in turn, public goods provision. In terms of postwar violence's effect on democracy, without a clear break from the violent past (in the form of demilitarization, for example), elections are likely to be dominated by questions related to security, which can jeopardize the transition to democracy (Lyons 2004). Finally, it is also reasonable to expect that to the degree any collective identity has been formed during the violent conflict, the sense of collectiveness may deteriorate in the postwar society if it is characterized by violence.

Indeed, an alternative source for internal legitimacy might be de facto states' nation-building (rather than state-building) efforts. Both states and de facto states may gain internal legitimacy by fostering a collective identity. Migdal (2001) notes that even states that are remarkably insufficient at providing their citizens with material wellbeing tend to survive, suggesting that their legitimacy has other sources, such as ceremonies and public rituals aimed at forging unity. In rebel-held territories, insurgent groups have mimicked the symbols associated with nation-states - such as flags, currency, and national anthems - as a means to foster consent and cohesiveness (Mampilly 2011:56-58). In the case of postwar and de facto states, such nation-building efforts may be highlighting the population's shared war experiences and common enemy to create collective solidarity (Lynch 2004; Kolstø 2006; OECD 2010; Blakkisrud and Kolst $\varnothing 2011$ ). While a sense of collective solidarity is likely to shape all forms of internal legitimacy, we anticipate that it would be particularly important for state legitimacy.

To empirically examine the determinants for internal legitimacy in de facto states, we draw upon a 2010 survey we directed in Abkhazia. Abkhazia is a de facto state whose population, as in Chechnya, Transnistria, South Ossetia, and Nagorno Karabakh, has seen fighting in the name of independent statehood both during and after the war of 1992-1993, as well as criminal violence during and after the war, making it a good case for exploring whether individual variation in experiences of security and safety in the postwar era affects the entity's legitimacy. Thus, the research design is a large-n analysis of micro-level variation within one de facto state. Before dis- cussing survey design and variables, we introduce the case of Abkhazia.

\section{War and Postwar Developments in Abkhazia}

An autonomous republic within Georgia, Abkhazia had, per the 1989 Soviet census, a population of 525,000, including Georgians (45.7\%), Russians (14.3\%), Armenians (14.6\%), and Abkhaz (17.8\%). A separatist war broke out in August 1992, spurred by tides of nationalism among both Georgians and Abkhaz. The titular Abkhaz population, despite their minority status, had in late Soviet times dominated positions of political power within the region. This Abkhaz dominance did not sit well with the ethnic Georgian majority or the growing nationalist movement in Tbilisi, particularly not in an era of heightened nationalist discourse in the waning days of the Soviet Union. While ethnic Georgians in Abkhazia feared that the non-Georgian-Abkhaz population would prevent Georgian independence from the USSR, the ethnic Abkhaz population was worried that they would end up in a disadvantaged position and also lose their language and culture in an independent Georgia. Hence, they called for Abkhazia to become a separate republic within the still-existing USSR. From 1988 to 1989, tensions escalated, and in August 1992, the troops of then-independent Georgia moved into Abkhazia. By September 1993, Abkhaz forces with external help had managed to take control, and in June 1994, the Abkhaz and Georgian authorities solidified this Abkhaz battlefield victory by agreeing to the deployment of a UN Observer Mission in Georgia (UNOMIG) as well as 3,000 Russian peacekeepers (Zürcher 2007:120-132). All ethnic groups suffered displacement during the Georgian-Abkhaz war, but 200,000-240,000 ethnic Georgians found themselves in protracted displacement beyond Abkhazia after the war (Toal and Grono 2011:656).

The ceasefire more or less held until 2008, although it was on several occasions challenged by border skirmishes and clashes between armed forces and civilians or paramilitary groups. In August 2008, Georgian forces attacked the other unrecognized state within its borders, South Ossetia, leading to a short-lived but deadly interstate conflict as Russian forces sided with South Ossetia to counter Georgian troops. Abkhaz forces, with the help of Russian air power, used the opportunity to establish control over the upper Kodor(i) Valley. The Abkhaz authorities consider the upper Kodor(i) Valley to be part of Abkhazia, based on the old Soviet boundaries, but it had been controlled by Georgians since the 1992-1993 war. Since the 2008 war, some 4,000-5,000 Russian security personnel have been stationed along the border with Georgia and in a new base, while the UNOMIG forces have withdrawn (ICG 2010:3).

As in other de facto states, the return of displaced/refugee populations to their prewar homes has spurred violent confrontations. In 1997-1998, the spontaneous return of thousands of Georgians led to border clashes in Gal(i) district in the south, ${ }^{10}$ which prior to the war was a Georgian-dominated region (96\% of the population there were largely Mingrelian-speaking, ethnic Georgians), resulting in the expulsion of 30,000-40,000 of the returnees (ICG 2006:11). The clashes were between the Abkhaz militia and a Georgian paramilitary group, the

\footnotetext{
${ }^{10}$ The Russian/Abkhaz spelling is Gal, and the Georgian spelling is Gali.
} 
White Legion (Lynch 2004:29-30), but also directed at civilians (Walker 1998:12). While the Abkhaz constituted only a minority in Abkhazia prior to the war, O'Loughlin, Kolossov and O'Tuathail (2011) estimate that $42.5 \%$ of the region's postwar population is Abkhaz, and the officials in the entity's government are predominantly ethnic Abkhaz. ${ }^{11}$ Despite inter-ethnic clashes, a number of Georgians had returned to Gal(i) district a decade after the conflict came to an end (Lynch 2004:52-54; International Crisis Group 2006:9-10). Today, the population in the still Georgian-dominated region is about 44,000, although many Georgians remain displaced. Human Rights Watch (2011) report widespread feelings of insecurity among Georgians in Gal(i). Indeed, a common statement in interviews in Gal(i) with the second and third authors in November 2009 is that this population feels like a "double minority" in both Abkhazia and in Georgia, whose government has accused the returnees of disloyalty. As we discuss below, this sense of insecurity among the Georgian population in Gal(i) has implications for the survey responses $(76 \%$ of the Georgians surveyed live in $\mathrm{Gal}(\mathrm{i}))$.

While the Abkhaz elite has been united in its separatist quest, Abkhazia has suffered from internal power struggles. The independence movement's leader and first president, Vladislav Ardzinba, was in the early 2000s increasingly challenged by the war veterans group Amtsakhara, which in 2003 helped bring down the government (Khashig 2003). In 2004, Amtsakhara's political secretary was assassinated, encouraging the opposition to call for the government's resignation (Anjaparidze 2004). The October elections the same year were disputed and followed by mass protests (Khashig 2004). A deal behind the scenes led to the opposition leader Sergei Bagapsh eventually emerging as the elected victor (he died in May 2011).

Recent years have seen assassinations and assassination attempts of high-profile political figures (ICG 2010:12), sometimes tied to criminal violence. Especially in Gal(i), until 2008, the activities of Abkhaz and Georgian criminal networks were easily conducted across the porous border. In 2009, it was reported that the Russian Interior Ministry had pledged support to combat crime and corruption in both Abkhazia and South Ossetia. ${ }^{12}$ In February 2012, Abkhazia's current president, Aleksandr Ankvab, who since coming to power in contested elections in fall 2011 eagerly has tried to clamp down on corruption, survived an assassination attempt, the sixth attempt on his life in the last decade. ${ }^{13}$ Despite this violence, parliamentary and presidential elections have been held consistently (O Beacháin 2012). We would expect that this kind of turmoil to engender feelings of insecurity that are likely to shape internal legitimacy.

\section{Research Design}

The 2010 public opinion survey that allows us to explore internal legitimacy in Abkhazia was designed by John

\footnotetext{
11 The 2011 census in Abkhazia, which is disputed by the Georgians, reports that ethnic Abkhaz now makes up 50.7\% of the population. See "The Population of Abkhazia Stands at 240,705," Apsny Press, December 30, 2011; available online at http://apsnypress.info/en/news/338.html (accessed July 26, 2012).

12 "Russian Policemen to Cooperate with Abkhazia, S Ossetia Colleagues," ITAR-TASS, November 12, 2009.

${ }^{13}$ Michael Schwirtz, "President of Abkhazia Survives Assassination Attempt," New York Times, February 22, 2012.
}

O'Loughlin, Vladimir Kolossov, and Gerard Toal (O'Loughlin et al. 2011). It was carried out by the Levada Center in Moscow, employing both Russian and local interviewers. O'Loughlin et al. established, through fieldwork, that it would be particularly important to use local Mingrelian- and Georgian-speaking interviewers in the south of Abkhazia, especially in Gal(i), where the population might be hesitant to answer sensitive questions asked by outsiders (Levada used local Georgian school teachers accompanied by their surveyors). The sample $(N=1000)$ reflects the Abkhaz government's estimates of ethnic distribution - a distribution disputed by the Georgian government. The survey sample includes $42.5 \%$ Abkhaz, 18.5\% Armenian, 12.5\% Georgians, $10.4 \%$ Russian, $7.4 \%$ Mingrelian, $4.3 \%$ Georgian/Mingrelian, and $4.4 \%$ of other, mixed, or unknown ethnic backgrounds. The official Georgian position is that the Mingrelian population is Georgian, but the local population uses the categories Mingrelian and Georgian/Mingrelian and could choose either category as their nationality in the survey; in the empirical analysis, we include all three categories in the dummy variable for ethnic Georgians. The primary sampling units (PSUs) were the 170 precincts used in Abkhazia's 2009 presidential election. The rural part of Gali(i) was not divided into electoral districts; hence, villages were used as PSUs. Of the PSUs, a random sample of 84 was selected, with 11-12 interviews in each, based on a random route method. The overall response rate was $67 \%$.

\section{Operationalization and Description of Variables}

The survey included more than 140 questions. For many questions, the Georgian respondents chose the "difficult to say/don't know" option; this strategy is possibly a way out of responding to politically sensitive and difficult questions. As we discuss below, to avoid that these respondents are systematically excluded from the analysis by treating them as missing observations, we use copula methods to impute these answers (Nelson 2010). That is, unless otherwise noted, all "difficult to say/don't know" answers (shown in the figures) are imputed in the empirical analysis. Summary statistics for the questions used in the analysis, including the imputed responses, are in the Appendix.

To assess state legitimacy, which we conceptualize as acceptance of the entity itself, we use a question that asks people what the status of Abkhazia should be. We distinguish among, on the one hand, those who say that Abkhazia should become part of Russia (about 24\%) or Georgia (about 4\%) and, on the other hand, those who think Abkhazia should "remain an independent state" (nearly 63\%). Our assumption is that those who accept the foundational myth of Abkhazia as independent see it as legitimate. As Figure 1 shows, there is variation across ethnic groups. Nearly half the Georgian respondents favor that Abkhazia remaining independent, but many also seem to opt for the choice "difficult to say" to avoid answering a contentious question. These responses suggest that for many Georgians currently in Abkhazia, the possibility of reintegration with uncontested Georgia is unrealistic, and they may have resigned to a pragmatic acceptance of Abkhazia's de facto independence.

Unsurprisingly, the majority of the ethnic Abkhaz population thinks that Abkhazia should be independent, and the majority of the respondents in favor of this option $(54 \%)$ identify as ethnic Abkhaz. We also use a second 

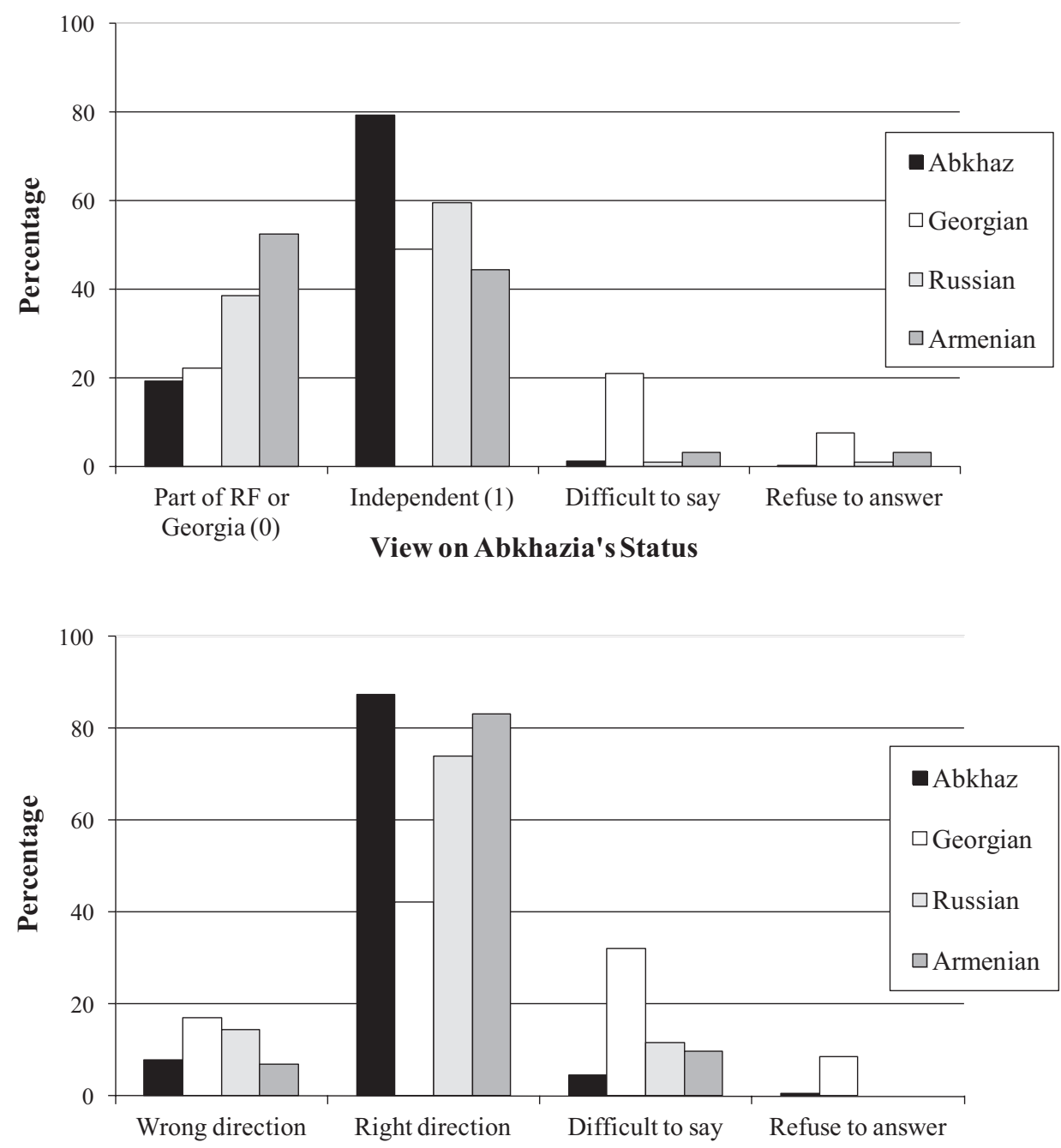

Is Abkhazia Moving in the Right Direction?

FIg 1. Two Measures for State Legitimacy, Responses by Major Ethnic Groups

measure for state legitimacy, a question that asks whether things in Abkhazia are moving in the right or wrong direction, which captures people's overall assessment of the de facto state's future. The majority responded that things are moving in the right direction, although again, there is variation across ethnic groups. ${ }^{14}$

To assess regime legitimacy, we asked the respondents whether they trust the ruling regime (the president and parliament). For institutional legitimacy, we rely on questions that inquire about people's trust in more permanent institutions, specifically the police and judiciary. ${ }^{15}$ Trust signals that people have faith in an institution (or person) and is, therefore, a suitable indicator for the acceptance - the legitimacy - of the ruler's right to rule. Figure 2 shows the breakdown by major ethnic groups for two of these indicators. Note that trust in the president, at the time Sergei Bagapsh, is very high also among Georgians. Bagapsh, who was married to an ethnic Georgian, was

\footnotetext{
${ }^{14}$ In this case, we recode the "difficult to say" answer to "moving in the wrong direction," as the answer indicates a certain level of doubt about where Abkhazia is going.

${ }^{15}$ For the questions capturing regime and institutional legitimacy, we recode the "difficult to say" answers to "no," as the answer indicates doubt about trusting the authority in question.
}

generally well liked, and the high trust we observe might be a personality effect. As for institutional legitimacy, less than half of the respondents expressed trust in the police and courts and law. Low trust in the police is not atypical for the post-Soviet world; our previous work shows that it is lower in the North Caucasus, where more than $90 \%$ of respondents in a 2005 survey distrusted the police. ${ }^{16}$

Per the state-building argument, the key independent variables hypothesized to shape internal legitimacy are democracy, economic public goods provision, and perceptions of security. The nation-building argument emphasizes a collective identity based around shared war experiences and a common enemy.

In terms of democracy, the data reveal a somewhat hesitantly positive outlook. In response to a question that asks respondents to assess, among a battery of similarly phrased questions, how significant a problem is "lack of democracy," more than half say it is "not a problem" or "no big problem." Honing in on individual experiences, people were also asked to assess how much influence they have on political life. Our expectation is that the less influence people think they have, the less likely they are

16 The North Caucasus project is available at http://www.colorado.edu/ ibs/waroutcomes (last accessed June 28, 2012). 


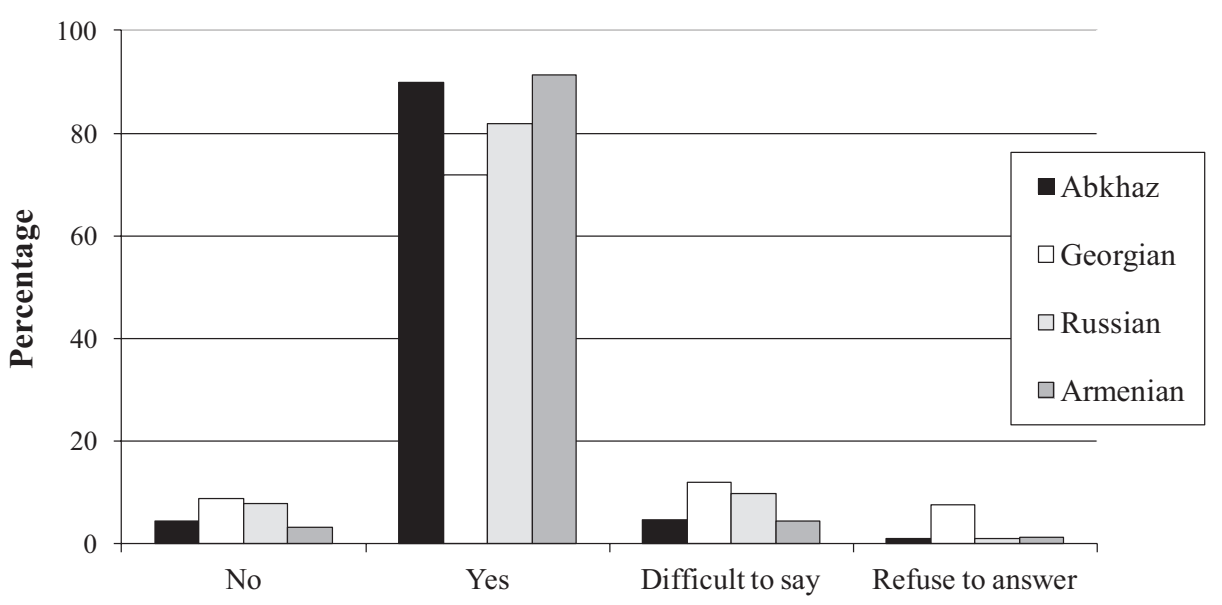

Do You Trust the President?

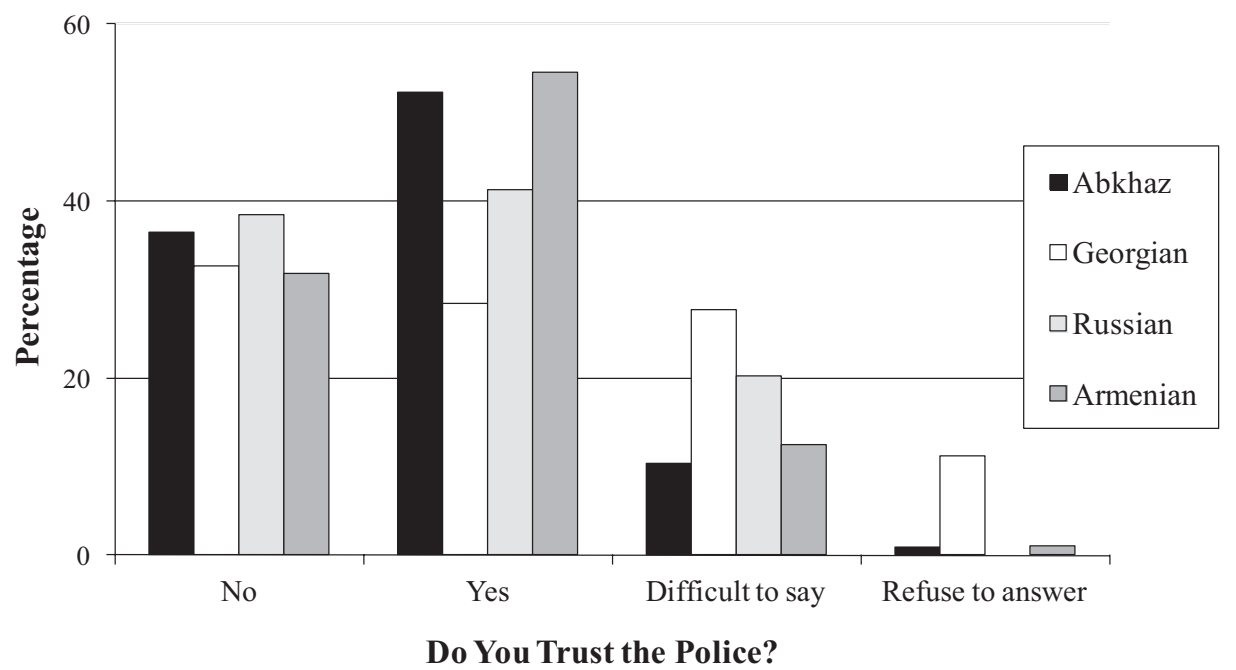

FIg 2. Trust in the President and the Police, Responses by Major Ethnic Groups

to have faith in the entity, the regime, and political institutions. Nearly $55 \%$ state they have little or no influence. Thus, these questions paint a mixed picture of people's perceptions of democracy in Abkhazia. Again, we note variation across ethnic groups (see O'Loughlin et al. 2011), with the Abkhaz relatively satisfied and the other groups more leery of the political sector, largely due to the entity's ethnocratic nature (Clogg 2008; Trier, Lohm, and Szakonyi 2011). Indeed, the president is required to be ethnic Abkhaz and fluent in the Abkhaz language (Blakkisrud and Kolstø 2012). At the time of the survey, only nine of 35 members of the parliament were of nonAbkhaz ethnic background.

To assess how the inhabitants in Abkhazia perceive the provision of economic public goods, we use a question that asks people how significant a problem lack of economic development and unemployment poses, as well as a question that asks them about the provision of public health services. ${ }^{17}$ As in the rest of the post-Soviet world, economic development is a worry, and almost $80 \%$ say that lack of economic development and unemployment is a "big problem" or a "rather big problem," suggesting that the ruling authority might be failing in this aspect of

${ }^{17}$ On economic insecurity and migration in Abkhazia, see Kolossov and O'Loughlin (2011). the social contract. In terms of public health provision, the outlook is somewhat better but still skeptical. The survey also asks the respondents to compare the economic situation in Abkhazia and its parent state, Georgia. One would expect that people who perceive the economic situation to be better in Abkhazia would also think more highly of the entity's internal legitimacy. Almost three in five say the situation seems "better" or "much better" in Abkhazia than in Georgia. While this comparison question is interesting and worth examining, it is potentially problematic as it is mainly the Georgian population living in Gal(i) who ever travels to Georgia (Toal and Grono 2011). To assess people's lived experience of public goods provision, the survey asks the respondents to rate their family's income level. There are differences within Abkhazia, but overall, about $70 \%$ said they "can purchase all they want" or "all they want apart from durable goods." So while many see lack in public goods provision as a problem, most nonetheless perceive the situation to be better in Abkhazia than in Georgia, and most appear to be able to put food on the table.

The survey includes several questions that capture people's feeling of postwar security and safety, in terms of both criminal and political violence. Key to the ruler's promise in the social contract is protection of subjects and their possessions. When asked about how great of a 




How Big of a Problem is Inter-Ethnic Hostility?

Fig 3. View on Inter-Ethnic Hostility, Responses by Major Ethnic Groups

problem is crime, almost as many saw it as a small or no problem as a problem. The same goes for the respondents' assessment of corruption. To assess feelings of insecurity related to political violence between the groups that were fighting one another during the war, respondents were asked to assess how significant a problem is increasing hostility between the various national groups in Abkhazia (Figure 3). The majority deemed this to be "no major problem" or "no problem at all." The picture was slightly different in Gal(i), which, since the 19921993 war, has been the scene of ethnicized clashes, where only $29 \%$ did not see it as a problem or only a small problem. People were also asked more directly about their own experience of discrimination on ethnic or religious grounds in the last 12 months, and the results show relatively little insecurity. As for the prospects of renewed war with Georgia, the majority considered this to be "no major problem" or "no problem at all," most likely due to the presence of Russian peacekeepers since the 2008 war. Overall, the survey reveals a greater sense of insecurity when it comes to criminal than political violence.

While our expectation is that individuals' perceptions of postwar violence will shape their assessment of the entity's internal legitimacy, we also control for experiences of wartime violence. It may be the case that those who suffered the most during the war are struggling with its aftermath and have a harder time believing in and trusting anyone, including those in power. To assess this, we use a question that asks whether the respondents or their close relatives witnessed violence during the war; more than $60 \%$ replied that they did.

The nation-building argument emphasizes that a strong sense of collective solidarity among the citizens of an unrecognized state is likely to boost the inhabitants' perception of the entity's legitimacy. We assess a sense of collective identity based on a survey question that asks people how they would name themselves "in the first place" - as belonging to their people, citizens of Abkhazia, citizens of Russia, "Soviet man," representative of one of the Circassian people, inhabitants of the Caucasus, citizen of Georgia, or other. Our expectation is that people who identify as citizens of Abkhazia are, based on their collective identification with the entity, likely to consider the regime and its institutions as legitimate. Among the survey respondents, more than $40 \%$ identify as Abkhaz citizens. Most of these are of Abkhaz ethnic background (52\%), while only $19 \%$ of the respondents identifying as Abkhaz citizens are of Georgian or Mingrelian background.

Key to the rationale for collective identity affecting internal legitimacy in postwar societies is that shared war experiences have created a notion of belonging together, united against a common enemy. To test this, we rely on a survey question that asks people how they "think now of the Georgians" (unspecified locationally). Ostensibly, this collective identity names the wartime out-group. If people feel negatively about the wartime out-group, they may be more likely to find the entity legitimate based on a clear common enemy image. This is an imperfect measure as not all Georgians were considered wartime enemies; we use it nevertheless, since it is revealing, as is also the case in other de facto states. We note, though, that official Abkhazian discourse continues the Soviet ethos of describing the state as multiethnic and inclusive, so "political correctness" entails no expression of negative feelings about Georgians (especially when prompted in surveys). The majority of respondents have positive feelings toward the Georgians. Most (nearly 70\%) of those who have bad feelings about the Georgians are respondents who identify as ethnic Abkhaz, although the Abkhaz are split on the question (37\% with good feelings and $35 \%$ with bad feelings).

Because of the ethnocratic nature of the state-building efforts in Abkhazia, we need to capture whether there are differences across ethnic groups. We control for whether respondents were Abkhaz, Georgian, or Russian (leaving the Armenians and the few respondents who identify as other as the reference group), expecting the Abkhaz population to find the entity more legitimate than any other ethnic group. We also expect the Russian population to view the entity and its regime as legitimate, given that Russia has formally recognized Abkhazia as a state.

We also control for gender and year of birth, which ranges from 1922 to 1992 . While we do not have any gender expectations, we anticipate that younger respondents, who have come of age and been socialized since Abkhazia gained its de facto status after the 1992-1993 war, are more likely to find the entity legitimate than older respondents, socialized in the Soviet context. 
TABLE 2. Original vs. Imputed Answers for Question on Inter-Ethnic Hostility

\begin{tabular}{ccccccc}
\hline & No Problem at All (1) & Not Big Problem (2) & Rather Big Problem (3) & Very Big Problem (4) & Difficult to Say & Refuse to Answer \\
\hline Original & 503 & 171 & 132 & 49 & 119 & 26 \\
Imputed & 514 & 232 & 160 & 68 & 0 & 26 \\
\hline
\end{tabular}

\section{Empirical Models}

Our base model for assessing internal legitimacy is based on micro-level variation, examining the role played by people's evaluation of democracy, welfare and material well-being, and security, as well as collective solidarity, wartime violence, ethnicity, gender, and year of birth. In general, the independent variables are coded so that the higher the score, say on a 1-4 scale, the bigger the perceived problem (see Appendix 1). We employ three sets of dichotomous variables for assessing internal legitimacy, using logistic regression. First, to assess state legitimacy, we rely on a question that indicates whether respondents think that Abkhazia should be an independent state or become part of Russia or Georgia, as well as a question that assesses people's view on whether Abkhazia is moving in the right direction (Table 1 ). Second, for regime legitimacy, we assess trust in the president and the parliament (Table 2). Third, for institutional legitimacy, we assess trust in the police and trust in the judiciary (Table 3). We proceed to discuss our main findings, followed by a brief discussion of robustness and goodness of fit.

To address the large number of Georgian respondents opting for the "difficult to say/don't know" answer options, we chose not to treat them as missing observations (which would drop them from the analysis, reducing the $\mathrm{N}$ to $440-460$ from 1000). ${ }^{18}$ Indeed, these answers are not missing but, most likely, the result of sense of insecurity felt by many Georgians in Abkhazia. We use copula methods to impute the responses in these categories. This means that the "difficult to say/don't know" category is treated as missing, and copula methods use all the available data to construct a joint density of all the variables, transformed to ranks (Hoff 2007). Once this joint density of the ranks is constructed, it can be sampled from repeatedly to provide a reasonable estimate of the information to be imputed. For example, the variable that asks about inter-ethnic hostility has 119 respondents opting for "difficult to say," but the copula method assigns these across the other answer categories. As Table 2 shows, most of the imputed responses end up in categories 2 and 3. The answer category "refuse to answer" does not appear to be a similarly popular option for those reluctant to answer contentious questions, so we leave this as is, which means that those respondents are dropped from the analysis.

\section{Findings}

We report our findings in Tables 3-5, using odds ratios. ${ }^{19}$ Recall that our independent variables are coded so that a higher score means that the issue identified, such as lack of economic development, is considered

\footnotetext{
${ }^{18}$ We also did the empirical analysis without imputing the "difficult to say" options, and our results are generally consistent with what we find when imputing (rather than dropping) these observations.

19 Odds ratios higher than one indicate a positive relationship, while odds ratios lower than one indicate a negative relationship.
}

more severe. With respect to the control variables, we note that the generational effect revealed in several of the models goes contrary to our expectation. Youth (higher birth year) is negatively associated with different forms of internal legitimacy. We would have expected people who have grown up and been socialized during Abkhazia's de facto state period to be more likely to see

TABLE 3. State Legitimacy

\begin{tabular}{|c|c|c|}
\hline & $\begin{array}{c}\text { Belief in Abkhazia's } \\
\text { Status } \\
\text { as Independent } \\
\text { Model } 1 \text { (Logistic) }\end{array}$ & $\begin{array}{c}\text { Abkhazia Moving } \\
\text { in the Right Direction } \\
\text { Model } 2 \text { (Logistic) }\end{array}$ \\
\hline \multicolumn{3}{|l|}{ Democracy } \\
\hline Democracy problems & $1.00(0.10)$ & $0.79(0.09)^{* *}$ \\
\hline Influence problems & $0.88(0.08)$ & $0.64(0.07) * * *$ \\
\hline \multicolumn{3}{|l|}{$\begin{array}{l}\text { Welfare provision and } \\
\text { well-being }\end{array}$} \\
\hline $\begin{array}{l}\text { Economic } \\
\text { development } \\
\text { problems }\end{array}$ & $1.01(0.10)$ & $0.73(0.10)^{* *}$ \\
\hline $\begin{array}{l}\text { Public health } \\
\text { provision } \\
\text { problems }\end{array}$ & $1.19(0.12)^{*}$ & $1.14(0.15)$ \\
\hline $\begin{array}{l}\text { Abkhazia-Georgia } \\
\text { comparison: } \\
\text { Abkhazia worse off } \\
\text { economically }\end{array}$ & $1.15(0.10)$ & $0.92(0.09)$ \\
\hline $\begin{array}{l}\text { Material situation } \\
\text { difficult }\end{array}$ & $0.74(0.08) * * *$ & $0.71(0.10)^{* *}$ \\
\hline \multicolumn{3}{|l|}{ Security and safety } \\
\hline Crime problems & $1.02(0.11)$ & $1.02(0.12)$ \\
\hline $\begin{array}{l}\text { Corruption } \\
\text { problems }\end{array}$ & $0.71(0.07)^{* * *}$ & $0.83(0.09) *$ \\
\hline Hostility problems & $1.03(0.11)$ & $0.81(0.10) *$ \\
\hline $\begin{array}{l}\text { Harassment } \\
\text { problems }\end{array}$ & $0.95(0.11)$ & $0.94(0.12)$ \\
\hline New war prospects & $0.94(0.11)$ & $0.79(0.10) *$ \\
\hline \multicolumn{3}{|l|}{ Collective solidarity } \\
\hline Abkhaz identity & $1.85(0.31) * * *$ & $1.49(0.29) * *$ \\
\hline $\begin{array}{l}\text { Negative toward } \\
\text { Georgians }\end{array}$ & $1.25(0.09)^{* * *}$ & $0.98(0.09)$ \\
\hline \multicolumn{3}{|l|}{ Wartime violence } \\
\hline Witnessed violence & $0.99(0.17)$ & $1.09(0.22)$ \\
\hline Abkhaz & $3.69(0.73) * * *$ & $1.35(0.34)$ \\
\hline Georgian & $4.13(1.12)^{* * *}$ & $0.48(0.15)^{* *}$ \\
\hline Russian & $2.00(0.52) * * *$ & $0.91(0.29)$ \\
\hline Year of birth & $1.00(0.00)$ & $0.99(0.01) *$ \\
\hline Gender & $0.79(0.13)$ & $1.24(0.24)$ \\
\hline$N$ & 889 & 887 \\
\hline Pseudo $R^{2}$ & 0.11 & 0.22 \\
\hline
\end{tabular}

Notes. Estimations are done in Stata 10. The table provides odds ratios. Robust standard errors are reported in parentheses. All "refuse to answer" observations are dropped from the analysis.

*Indicates statistical significance at 0.10

**Indicates statistical significance at 0.05 .

*** Indicates statistical significance at 0.01 . 
the regime as legitimate. We briefly note the gender effect revealed in Model 6: Women are more likely than men to trust the judiciary.

\section{Democracy}

People's perception of influence and democratic practices are important determinants for internal legitimacy. Indeed, people's worries about the hands-on matter of whether they can influence what is happening in Abkhazia shape all forms of internal legitimacy. The influence variable assesses people's perceptions of their ability to shape what is going on in Abkhazia on a four-point scale, where a higher number indicates that the respondents find that they have less influence. Respondents who report having little influence are likely to be skeptical when asked whether things are moving in the right direction (Model 2). Similarly, people's perceptions of lack of influence have a strong effect on both regime (Models 3 and 4) and institutional legitimacy (Models 5 and 6). The survey question that asked people more generally about whether they think the absence of democracy is a problem for Abkhazia reveals that, the bigger the perception of a democratic deficit, the less likely they are to be positive about the future (Model 2) or trust the president (Model 4). This more general question about democratic problems does not seem to shape people's perceptions of institutional legitimacy, and our analysis shows that internal legitimacy, in all its forms, is more strongly affected by people's direct concerns about their own ability to influence the polity.

\section{Welfare Provision}

Key to the ruler's obligation in the social contract is providing material security. We find that people's assessment of their family's material well-being is important for state legitimacy but not for other forms of legitimacy. The worse off people are, the less likely they are either to favor Abkhazia as independent (Model 1) or believe that it is moving in the right direction (Model 2). These findings are consistent with expectations in the literature, but people's assessment of their material situation does not have a similar negative effect on regime and institutional legitimacy.

Economic public goods such as development and employment appear to shape both state and regime legitimacy. The larger the problem that lack of economic development and unemployment appears to respondents, the less likely they are to believe that Abkhazia is moving in the right direction (Model 2) and trust the parliament (Model 4). Institutional legitimacy is not shaped by economic public goods provisions, but we find that the provision of quality public health services does affect both trust in the judiciary (Model 6) and the president (Model 3 ). As far as state legitimacy goes, perceptions of problems associated with provision of public health services have, unexpectedly, a weakly positive effect on people's views on Abkhazia's status (Model 1, significant at the 0.1 level), but do not affect their view of the future. The positive effect we observe in Model 1, which contrasts with the negative effect observed in Models 3 and 6, could be a result of people assessing that problems of public good provision, such as health services, might be resolved if Abkhazia were to be independent. We note that this finding does not hold up in the alternative model specifications discussed below.
Table 4. Regime Legitimacy: Trust in the President and Parliament

\begin{tabular}{|c|c|c|}
\hline & $\begin{array}{l}\text { Trust in President } \\
\text { Model } 3 \text { (Logistic) }\end{array}$ & $\begin{array}{l}\text { Trust in Parliament } \\
\text { Model } 4 \text { (Logistic) }\end{array}$ \\
\hline \multicolumn{3}{|l|}{ Democracy } \\
\hline Democracy problems & $0.82(0.12)$ & $0.79(0.08) * *$ \\
\hline Influence problems & $0.55(0.09) * * *$ & $0.68(0.07)^{* * *}$ \\
\hline \multicolumn{3}{|l|}{$\begin{array}{l}\text { Welfare provision and } \\
\text { well-being }\end{array}$} \\
\hline $\begin{array}{l}\text { Economic } \\
\text { development problems }\end{array}$ & $1.17(0.21)$ & $0.78(0.10) * *$ \\
\hline $\begin{array}{l}\text { Public health } \\
\text { provision problems }\end{array}$ & $0.69(0.12) * *$ & $0.92(0.10)$ \\
\hline $\begin{array}{l}\text { Abkhazia-Georgia } \\
\text { comparison: } \\
\text { Abkhazia worse } \\
\text { off economically }\end{array}$ & $0.90(0.11)$ & $0.93(0.08)$ \\
\hline Material situation difficult & $1.07(0.19)$ & $0.95(0.11)$ \\
\hline \multicolumn{3}{|l|}{ Security and safety } \\
\hline Crime problems & $1.10(0.16)$ & $1.09(0.11)$ \\
\hline Corruption problems & $0.64(0.10) * * *$ & $0.69(0.07) * * *$ \\
\hline Hostility problems & $1.13(0.16)$ & $0.87(0.09)$ \\
\hline Harassment problems & $1.08(0.18)$ & $0.94(0.11)$ \\
\hline New war prospects & $0.72(0.10) * *$ & $1.04(0.12)$ \\
\hline \multicolumn{3}{|l|}{ Collective solidarity } \\
\hline Abkhaz identity & $2.25(0.55) * * *$ & $1.56(0.26)^{* * *}$ \\
\hline $\begin{array}{l}\text { Negative toward } \\
\text { Georgians }\end{array}$ & $1.02(0.11)$ & $0.87(0.07) *$ \\
\hline \multicolumn{3}{|l|}{ Wartime violence } \\
\hline Witnessed violence & $1.48(0.35)^{*}$ & $0.84(0.15)$ \\
\hline Abkhaz & $0.85(0.26)$ & $1.20(0.25)$ \\
\hline Georgian & $1.08(0.46)$ & $0.77(0.23)$ \\
\hline Russian & $0.74(0.28)$ & $1.04(0.28)$ \\
\hline Year of birth & $0.98(0.01) * * *$ & $1.00(0.00)$ \\
\hline Gender & $1.01(0.23)$ & $1.27(0.21)$ \\
\hline$N$ & 883 & 879 \\
\hline Pseudo $R^{2}$ & 0.17 & 0.14 \\
\hline
\end{tabular}

Notes. Estimations are done in Stata 10. The table provides odds ratios. Robust standard errors are reported in parentheses. All "refuse to answer" observations are dropped from the analysis.

*Indicates statistical significance at 0.10 .

**Indicates statistical significance at 0.05 .

$* * *$ Indicates statistical significance at 0.01 .

We do not find support for the idea that an unfavorable Abkhazia-Georgia comparison shapes people's perceptions of internal legitimacy. We had expected people who assess the economic situation in Abkhazia to be worse (almost 12\%) or much worse (almost 9\%) than in Georgia to be less likely to see Abkhazia, its regime, and its state institutions as legitimate. We speculate that this non-finding might be driven by the Georgians in the sample, most of whom live in Gal(i) district and who are likely to see anywhere as better than Gal(i). ${ }^{20}$ To examine this speculation, we dropped the respondents identifying as Georgians from the sample. Surprisingly, we found that by doing so, an unfavorable comparison boosted belief in Abkhazia's independence, possibly because people believe it is the entity's undefined status that causes a discrepancy, but the analysis otherwise yielded similar non-findings for the variable.

\footnotetext{
20 The survey shows that ethnic Georgians are more pessimistic about the prospects of improved future living conditions than other ethnic groups.
} 
TABLE 5. Institutional Legitimacy: Trust in State Institutions

\begin{tabular}{|c|c|c|}
\hline & $\begin{array}{c}\text { Trust in Police } \\
\text { Model } 5 \text { (Logistic) }\end{array}$ & $\begin{array}{l}\text { Trust in Judiciary } \\
\text { Model } 6 \text { (Logistic) }\end{array}$ \\
\hline \multicolumn{3}{|l|}{ Democracy } \\
\hline Democracy problems & $0.88(0.08)$ & $0.94(0.09)$ \\
\hline Influence problems & $0.64(0.06)^{* * *}$ & $0.62(0.06) * * *$ \\
\hline \multicolumn{3}{|l|}{$\begin{array}{l}\text { Welfare provision and } \\
\text { well-being }\end{array}$} \\
\hline $\begin{array}{l}\text { Economic } \\
\text { development problems }\end{array}$ & $0.86(0.08)$ & $0.97(0.10)$ \\
\hline $\begin{array}{l}\text { Public health } \\
\text { provision problems }\end{array}$ & $0.95(0.09)$ & $0.71(0.07) * * *$ \\
\hline $\begin{array}{l}\text { Abkhazia-Georgia } \\
\text { comparison: } \\
\text { Abkhazia worse } \\
\text { off economically }\end{array}$ & $0.91(0.07)$ & $0.93(0.07)$ \\
\hline $\begin{array}{l}\text { Material situation } \\
\text { difficult }\end{array}$ & $0.98(0.10)$ & $0.90(0.10)$ \\
\hline \multicolumn{3}{|l|}{ Security and safety } \\
\hline Crime problems & $0.79(0.07)^{* * *}$ & $0.84(0.08) *$ \\
\hline Corruption problems & $0.75(0.07) * * *$ & $0.70(0.06) * * *$ \\
\hline Hostility problems & $0.99(0.10)$ & $1.00(0.10)$ \\
\hline Harassment problems & $1.00(0.11)$ & $1.01(0.11)$ \\
\hline New war prospects & $1.01(0.11)$ & $1.01(0.11)$ \\
\hline \multicolumn{3}{|l|}{ Collective solidarity } \\
\hline Abkhaz identity & $1.21(0.18)$ & $1.28(0.20)$ \\
\hline $\begin{array}{l}\text { Negative toward } \\
\text { Georgians }\end{array}$ & $0.95(0.06)$ & $1.00(0.07)$ \\
\hline \multicolumn{3}{|l|}{ Wartime violence } \\
\hline Witnessed violence & $0.89(0.15)$ & $0.84(0.14)$ \\
\hline Abkhaz & $0.77(0.15)$ & $1.04(0.19)$ \\
\hline Georgian & $0.66(0.18)$ & $0.71(0.20)$ \\
\hline Russian & $0.70(0.18)$ & $0.85(0.22)$ \\
\hline Year of birth & $0.99(0.00)^{* *}$ & $0.99(0.00)^{* *}$ \\
\hline Gender & $1.20(0.18)$ & $1.32(0.20)^{*}$ \\
\hline$N$ & 879 & 875 \\
\hline Pseudo- $R^{2}$ & 0.12 & 0.15 \\
\hline
\end{tabular}

Notes. Estimations are done in Stata 10. The table provides odds ratios. Robust standard errors are reported in parentheses. All "refuse to answer" observations are dropped from the analysis.

*Indicates statistical significance at 0.10 .

**Indicates statistical significance at 0.05 .

****Indicates statistical significance at 0.01 .

Security

Questions about protection from internal and external dangers get at the core of what it means to be a state; hence, we would expect that such concerns are strong drivers for internal legitimacy. In the empirical analysis, we include several variables that capture perceptions of insecurity associated with crime, corruption, and more politically oriented violence.

Our analysis clearly shows that people's perceptions of crime and corruption are key determinants for all forms of internal legitimacy. A consistently negative and significant influence of corruption is not surprising, as the survey reveals much concern about people's economic prospects, which is closely tied to corruption. Indeed, Moore (1978:28) reflects that, "although the moral attitudes toward bribery and the participants vary greatly in time and space (social as well as geographic), there appears to be a common core of negative attitudes to it."

We find less consistent support for concerns about political violence shaping internal legitimacy. People's experiences of harassment have no significant bearing on any form of internal legitimacy, but as expected, to the extent that inter-ethnic hostilities are perceived as prob- lematic, it's also less likely that respondents believe that Abkhazia is moving in the right direction (Model 2). As expected, given that protecting citizens from external threats is central to what it means to be a functioning state, we also find that the more people are concerned about the prospects for a new war with Georgia, the less likely they are to think that Abkhazia is moving in the right direction (Model 2) and the less likely they are to trust the president (Model 3). Given that Russia now guarantees the external security of Abkhazia (and South Ossetia), the population now has less reason to fear renewed war with Georgia, which might explain why this fear is not shaping all indicators for internal legitimacy (O'Loughlin et al. 2011).

While we had also expected experience of wartime violence to negatively shape internal legitimacy, we found instead that witnessing violence during the 1992-1993 war had a positive effect on trust in the president (Model 3 ). While this goes against the conventional wisdom in the conflict resolution literature, it is consistent with a growing body of research pointing to how experiences of violence actually may boost social capital, political participation, and altruistic behavior (for example, Staub 2005; Blattman 2009).

\section{Nation-Building: Collective Solidarity vs. Ethnic Identities}

As expected, based on the nation-building argument, a civic identity as citizen of Abkhazia is positively correlated with both state and regime legitimacy. The odds that a respondent favors an independent Abkhazia (Model 1), believes that Abkhazia is moving in the right direction (Model 2), and trusts in both president (Model 3) and parliament (Model 4) are much higher if a respondent identifies as a citizen of Abkhazia than if a respondent holds any other non-ethnic identity (such as identification as citizen of Russia, "Soviet man," representative of the Circassian people, inhabitant of the Caucasus, or citizen of Georgia). We do not find that a collective civic identity with the entity itself shapes people's trust in the police and judiciary, suggesting that such identity is more important for state and regime legitimacy than for institutional legitimacy. Indeed, as discussed above, the legitimacy of the police and judiciary is driven by concerns related to state-building, rather than to nation-building. We also find that our second indicator for collective solidarity, which more directly assesses what people think about the wartime out-group, "the Georgians," shapes state legitimacy. The more negatively people feel about the wartime out-group, the more likely they are to prefer an independent Abkhazia (Model 1). Contrary to our expectations, we find that people who feel negatively toward the Georgians are less likely to trust the parliament (Model 4). It might be that the contradictory (and non-) findings on the effect of people's perceptions of Georgians is that the variable, as noted above, does not adequately capture the particularistic dynamics of the Abkhazian case; importantly, as noted, not all Georgians were considered wartime enemies.

Our findings also reveal that our control variables for more exclusive ethnic identities have a strong influence on state legitimacy, but not for other forms of internal legitimacy. Identification as ethnic Georgian is negatively correlated with thinking that Abkhazia is moving in the right direction (Model 2), and there is a positive correlation between respondents identifying as ethnic Abkhaz and support for Abkhazia remaining an independent 
state (Model 1). The ethnic Russian respondents appear to also favor Abkhazia remaining independent, which is unsurprising, as many of the Russians who stayed after 1991 are well integrated and doing relatively well economically. More surprising is that the model shows a positive correlation between identification as ethnic Georgian and support for Abkhazia remaining independent. This is undoubtedly a controversial finding that requires further research. Recall from Figure 1 that about half of the Georgian respondents say that Abkhazia should remain independent. When we impute the relatively large number of "difficult to say" responses among the Georgians, this share increases to $69 \%$. To make sure that the surprising finding is not a result of our imputation strategy, we also went for the option of simply dropping from the analysis all respondents going for "difficult to say," which still left us with a similar result (but smaller $N$ of 444). We also divided the Georgian respondents into those living in Gal(i) and those living elsewhere, but for either category of Georgians, we find a positive correlation. There might be a segment of the ethnic Georgian population in Abkhazia that are resigned to what appears to be a powerful and enduring status quo, the de facto independence of Abkhazia. Their attitude could thus be described as a pragmatic status quo choice.

\section{Robustness and Goodness of Fit}

To ensure that our findings hold up to alternative model specifications, we used alternative measures for some of our independent variables (see Appendix 1). To assess the existence of a shared wartime enemy group, we ran alternative models using a question that asked people whom they blamed for the war. To assess people's view of their political influence, we used an alternative measure that asked them about how they can most likely achieve the solution to their problems-by going through routine political channels, via rallies and strikes, or simply stating they have no routes available. Finally, while the models reported above controlled for the experience of wartime violence by assessing whether the respondents or their close relatives witnessed violence during the 1992-1993 war, as an alternative we used a question that asked people whether their home was damaged in the war. While Model 3 showed that witnessing violence during the 1992-1993 war positively affected trust in the president, we do not find that experiences of one's home being destroyed has a similarly unexpected effect; rather, we find that wartime destruction of one's home negatively shapes trust in the police (Model 5) and judiciary (Model 6 ). In general, using alternative specifications does not significantly alter our inferences.

To assess the models' goodness of fit, we examined their ability to predict outcomes on the dependent variable within the sample used. As Table 6 shows, there is still unexplained variance in our models, which have higher levels of sensitivity than specificity and higher positive predictive value than negative predictive value. We also looked at the area under the ROC (receiver operating characteristic) curve, which is calculated based on a model's ability to predict, ranging from 0.5 to 1 . A model that produces events and non-events with equal probability will receive a score of 0.5 , while a model that correctly predicts all events and non-events will receive a score of 1. For our models, the score ranges from 0.72 to 0.81 , with the strongest performance for the model examining Abkhazia's direction and trust in the president.

\section{Conclusion}

In this article, we have empirically tested a set of hypotheses surrounding internal legitimacy in de facto states, using original 2010 survey data from Abkhazia. We propose that internal legitimacy is likely to be shaped by the local population's perceptions of the de facto state's state-building efforts. Indeed, while questions about statebuilding are important for any postwar society, they may be particularly pertinent for de facto states born out of violent struggles, as these are entities that are trying to make it on their own in the international system. They need to convince both their own populations and the international community that they are, indeed, statebuilders.

Disaggregating the concept of internal legitimacy into distinct dimensions - looking at people's confidence and belief in the polity itself, its ruling regime, and institutions - we are particularly interested in how people's perceptions of security and safety in the postwar era shape internal legitimacy. We find that people's perceptions of corruption are likely to have negative effects for all forms of internal legitimacy. Indeed, this is the only variable that shapes every measure for internal legitimacy. We find only limited evidence of concerns about internal political violence matters, but the danger of war recurrence does, indeed, loom in the background. While there are unique aspects of Abkhazia as a case, the study suggests that variables likely to shape internal legitimacy in other contexts (in states and insurgent states) are useful starting points for explaining how legitimate the people perceive the entity, its regime, and institutions. The study reveals that people's concerns about the provision of public goods such as democracy, economic development, and health services are, in addition to perceptions of safety and security (or lack thereof), important determinants for internal legitimacy. Thus, our findings suggest that internal legitimacy is not tied only to the key Weberian state-building function of monopoly of the legitimate use of force; people are just as concerned about these entities' ability to fulfill other aspects of the social contract.

Table 6. In-Sample Predictions

\begin{tabular}{|c|c|c|c|c|c|c|}
\hline & \multicolumn{2}{|c|}{ State Legitimacy } & \multicolumn{2}{|c|}{ Regime Legitimacy } & \multicolumn{2}{|c|}{ Institutional Legitimacy } \\
\hline & Model 1: Status & Model 2: Future & Model 3: President & Model 4: Parliament & Model 5: Police & Model 6: Judiciary \\
\hline Sensitivity & $90.75 \%$ & $94.91 \%$ & $98.84 \%$ & $92.01 \%$ & $65.57 \%$ & $72.01 \%$ \\
\hline Specificity & $29.30 \%$ & $34.67 \%$ & $9.43 \%$ & $33.60 \%$ & $67.69 \%$ & $67.36 \%$ \\
\hline Positive predictive value & $74.34 \%$ & $83.40 \%$ & $88.89 \%$ & $77.42 \%$ & $65.41 \%$ & $69.35 \%$ \\
\hline Negative predictive value & $58.39 \%$ & $66.35 \%$ & $52.63 \%$ & $62.96 \%$ & $67.84 \%$ & $70.12 \%$ \\
\hline Area under the ROC curve & 0.72 & 0.81 & 0.79 & 0.74 & 0.73 & 0.75 \\
\hline
\end{tabular}


These findings speak to bigger questions about statebuilding and internal legitimacy, both generally and in the context of Abkhazia. State-building is rarely, if ever, simply internal. Abkhazia enjoys considerable financial support from the Russian Federation in the wake of the August 2008 war. So also did the government of Georgia, with pledges of approximately $\$ 4.5$ billion in aid for reconstruction, resettlement, and economic recovery after the war. As such, internal legitimacy cannot be seen in isolation from external relations. Given that there is still unexplained variance in the models examined in this study, a fruitful avenue for future research would comparatively probe whether the constituent dimensions of internal legitimacy have similar sources in recognized states and de facto states, as well as whether entities and de facto states in different geopolitical contexts can be analyzed using similar models (Toal 2013; Toal and O’Loughlin 2013).

\section{References}

Anderson, Liam. (2010) Reintegrating Unrecognized States: Internationalizing Frozen Conflicts. In Unrecognized States in the International System, edited by Nina Caspersen and Gareth Stansfield. London: Routledge.

Anjaparidze, Zaal. (2004) Infighting Plagues Abkhaz Separatist Camp. Eurasia Daily Monitor 1 (39): June 24. Available at www.jamestown. org/programs/edm. (Accessed October 25, 2013).

Atlas, Pierre M., and Roy Licklider. (1999) Conflict among Former Allies after Civil War: Sudan, Zimbabwe, Chad, and Lebanon. Journal of Peace Research 36: 35-54.

Autesserre, Severine. (2009) Hobbes and the Congo: Frames, Local Violence, and International Intervention. International Organization 63: 249-280.

Bakke, Kristin M. (2011) After the War Ends: Violence and Viability of Post-Soviet Unrecognized States. In Unrecognized States in the International System, edited by Nina Caspersen and Gareth Stansfield. London: Routledge.

Barakat, Sultan. (2005) Introduction: Post-War Reconstruction and Development-Coming of Age. In After the Conflict: Reconstruction and Development in the Aftermath of War, edited by Sultan Barakat. New York: Palgrave Macmillan.

Berg, Eiki. (2012) Parent States versus Secessionist Entities: Measuring Political Legitimacy in Cyprus, Moldova and Bosnia \& Hercegovina. Europe-Asia Studies 64: 1271-1296.

Berg, Eiki, and Martin Mölder. (2012) Who is Entitled to "Earn Sovereignty"? Legitimacy and Regime Support in Abkhazia and Nagorno-Karabakh. Nations and Nationalism 18: 527-545.

Blakkisrud, Helge, and PÅl Kolstø. (2011) From Secessionist Conflict toward a Functioning State: Processes of State- and Nation-Building in Transnistria. Post-Soviet Affairs 27: 178-210.

Blakkisrud, Helge, and Pål Kolstø. (2012) Yielding to the Sons of the Soil: Abkhazian Democracy and the Marginalization of the Armenian Vote. Ethnic and Racial Studies April 27, iFirst Article, pp. $1-21$.

Blattman, Christopher. (2009) From Violence to Voting: War and Political Participation in Uganda. American Political Science Review 103: 231-247.

Boyle, Michael. (2009) Explaining Strategic Violence after Wars. Studies in Conflict and Terrorism 32: 209-236.

CaSpersen, Nina. (2008) Separatism and Democracy in the Caucasus. Survival 50: 113-136.

Caspersen, Nina, and Gareth Stansfield, Eds. (2010) Unrecognized States in the International System. London: Routledge.

Clogg, Rachel. (2008) The Politics of Identity in Post-Soviet Abkhazia: Managing Diversity and Unresolved Conflict. Nationalities Papers 36: 305-329.

Collier, Paul. (2009) Post-Conflict Recovery: How Should Policies be Distinctive. Journal of African Economies 18: 99-131.

Gilley, Bruce. (2006) The Determinants of State Legitimacy: Results for 72 Countries. International Political Science Review 27: 47-71.
Hoff, Peter D. (2007) Extending the Rank Likelihood for Semiparametric Copula Estimation. Annals of Applied Statistics 1: 265283.

Human Rights Watch. (2011) Living in Limbo: The Rights of Ethnic Georgian Returnees to the Gali District of Abkhazia. New York: Human Rights Watch. Available at www.hrw.org/reports/2011/07/15/ living-limbo-0. (Accessed October 25, 2013).

International Crisis Group. (2006) Abkhazia Today. Europe Report No. 176, September 15. Tbilisi/Brussels: International Crisis Group. Available at www.crisisgroup.org/ /media/Files/europe/176_ abkhazia_today.ashx. (Accessed October 25, 2013).

International Crisis Group. (2010) Abkhazia: Deepening Dependence. Europe Report No. 202, February 26. Sukhumi/Tbilisi/Istanbul/ Brussels: International Crisis Group. Available at www.crisisgroup.org/ /media/Files/europe/202_abkhazia_deepening_dependence.ashx. (Accessed October 25, 2013).

Kang, Seonjou, and James Meernik. (2009) Civil War Destruction and the Prospects for Economic Growth. Journal of Politics 67: 88-109.

Kasfir, Nelson. (2005) Guerrillas and Civilian Participation: The National Resistance Army in Uganda, 1982-1986. Journal of Modern African Studies 43: 271-296.

Khashig, Inal. (2003) Abkhazia: Veterans Challenge President. Caucasus Reporting Service No. 187, July 31. Available at http:// iwpr.net/programme/caucasus. (Accessed October 25, 2013).

Khashig, Inal. (2004) Abkhazia's Political Roulette Goes On. Caucasus Reporting Service No. 262, November 17. Available at http://iwpr. net/programme/caucasus. (Accessed October 25, 2013).

King, Charles. (2001) The Benefits of Ethnic War: Understanding Eurasia's Unrecognized States. World Politics 53: 524-552.

Kolossov, Vladimir, and John O'Loughlin. (2011) After the Wars in the South Caucasus State of Georgia: Economic Insecurities and Migration in the "De Facto" States of Abkhazia and South Ossetia. Eurasian Geography and Economics 52: 631-654.

Kolstø, PÅL. (2006) The Sustainability and Future of Unrecognized Quasi-States. Journal of Peace Research 43: 723-740.

Lake, David. (2010) Building Legitimate States after Civil Wars. In Strengthening Peace in Post-Civil War States: Transforming Spoilers into Stakeholders, edited by Caroline Hartzell and Matthew Hoddie. Chicago, IL: University of Chicago Press.

Lynch, Dov. (2004) Engaging Eurasia's Separatist States: Unresolved Conflicts and De Facto States. Washington, DC: United States Institute of Peace Press.

Lyons, Terrence. (2004) Transforming the Institutions of War: Postconflict Elections and the Reconstruction of Failed States. In When States Fail: Causes and Consequences, edited by Robert I. Rotberg. Princeton, NJ: Princeton University Press.

Mampilly, Zachariah C. (2011) Rebel Rulers: Insurgent Governance and Civilian Life During War. Ithaca, NY: Cornell University Press.

McColl, Roвert W. (1969) The Insurgent State: Territorial Bases of Revolution. Annals of the Association of American Geographers 59: 613631.

Migdal, Joel. (1988) Strong States and Weak Societies: State-Society Relations and State Capabilities in the Third World. Princeton, NJ: Princeton University Press.

Migdal, Joel. (2001) State in Society: Studying How States and Societies Transform and Constitute One Another. New York: Cambridge University Press.

Mishler, William, and Richard Rose. (2001) What Are the Origins of Political Trust? Testing Institutional and Cultural Theories in PostCommunist Societies. Comparative Political Studies 34: 30-62.

Moore, Barrington Jr. (1978) Injustice: The Social Bases of Obedience and Revolt. London: The Macmillan Press.

Mulaj, Klejda. (2010) International Actions and the Making and Unmaking of Unrecognized States. In Unrecognized States in the International System, edited by Nina Caspersen and Gareth Stansfield. London: Routledge.

Nelson, Roger B. (2010) An Introduction to Copulas, 2nd edn. New York: Springer.

Norris, PIPPA. (1999) Institutional Explanations for Political Support. In Critical Citizens: Global Support for Democratic Government, edited by Pippa Norris. Oxford: Oxford University Press.

Ó Beacháin, Donnacha. (2012) The Dynamics of Electoral Politics in Abkhazia. Communist and Post Communist Studies 45: 165-174. 
O’Loughlin, John, Vladimir Kolossov, and Gearóid Ó'Tuathail. (2011) Inside Abkhazia: A Survey of Attitudes in a De Facto State. Post-Soviet Affairs 27: 1-36.

Organization for Economic Cooperation and Development (OECD). (2010) The State's Legitimacy in Fragile Situations: Unpacking Complexity. Paris: OECD.

PegG, Scотt. (1999) International Society and the De Facto State. Aldershot: Ashgate.

Reno, William. (2002) Mafiya Troubles, Warlord Crises. In Beyond State Crisis? Postcolonial African and Post-Soviet Eurasia in Comparative Perspective, edited by Mark R. Beissinger and Crawford Young. Washington, DC: Woodrow Wilson Center Press.

Schlichte, Klaus. (2009) In the Shadow of Violence: The Politics of Armed Groups. Chicago, IL: Chicago University Press.

Scott, James C. (1972) The Erosion of Patron-Client Bonds and Social Change in Rural Southeast Asia. Journal of Asian Studies 32: $5-37$.

Seligson, Mitchell A. (2002) The Impact of Corruption on Regime Legitimacy: A Comparative Study of Four Latin American Countries. The Journal of Politics 64: 408-433.

Seymour, Lee. (2012) Legitimacy and the Politics of Recognition in Kosovo and Abkhazia. Paper Presented at the annual convention of the Association for the Study of Nationalities, New York, April 1921.

Stanislawski, Bartosz, Ed. (2008) The Forum: Para-States, Quasi-States and Black Spots: Not States, But Not "Ungoverned Territories" Either. International Studies Review 10: 366-396.

Staub, Ervin. (2005) The Roots of Goodness: The Fulfillment of Basic Human Needs and the Development of Caring, Helping, and Nonaggression, Inclusive Caring, Moral Courage, Active Bystandership, and Altruism Born of Suffering. In Moral Motivation Through the Life Span, edited by Gustavo Carlo and Carolyn P. Edwards. Lincoln, NE: University of Nebraska Press.
Tilly, Charles. (1985) War Making and State Making as Organized Crime. In Bringing the State Back In, edited by Peter B. Evans, Dietrich Rueschmeyer and Theda Skocpol. Cambridge, UK: Cambridge University Press.

Toal, Gerard. (2013) "Republika Srpska Will Have a Referendum:" The Rhetorical Politics of Milorad Dodik. Nationalities Papers 41: 160204.

Toal, Gerard, and Magdalena F. Grono. (2011) After Ethnic Violence in the Caucasus: Attitudes of Local Abkhazians and Displaced Georgians in 2010. Eurasian Geography and Economics 52: 655-678.

Toal, Gerard, and John O'Loughlin. (2013) Inside South Ossetia: A Survey of Attitudes in a De Facto State. Post-Soviet Affairs 29: 136-172.

Trier, Tom, Hedvig Lohm, and David Szakonyi. (2011) Under Siege: InterEthnic Relations in Abkhazia. New York: Columbia University Press.

Walker, Edward. (1998) No Peace, No War in the Caucasus: Secessionist Conflicts in Chechnya, Abkhazia, and NagornoKarabakh. Occasional Paper, Belfer Center for Science and International Affairs, Harvard University.

Weber, Max. (1958) Politics as a Vocation. In Essays in Sociology, translated and edited by Hand H. Gerth and Charles W. Mills. New York: Oxford University Press.

Weber, Max. (1978) The Types of Legitimate Domination. In Economy and Society, translated and edited by Guenther Roth and Claus Wittich. Berkeley, CA: University of California Press.

Wickham-Crowley, Timothy. (1987) The Rise (and Sometimes Fall) of Guerrilla Governments in Latin America. Sociological Forum 2: 473499.

Wood, Elisabeth J. (2003) Insurgent Collective Action and Civil War in El Salvador. New York: Cambridge University Press.

Zürcher, Christoph. (2007) The Post-Soviet Wars: Rebellion, Ethnic Conflict, and Nationhood in the Caucasus. New York: New York University Press. 
Kristin M. BAKKe ET AL.

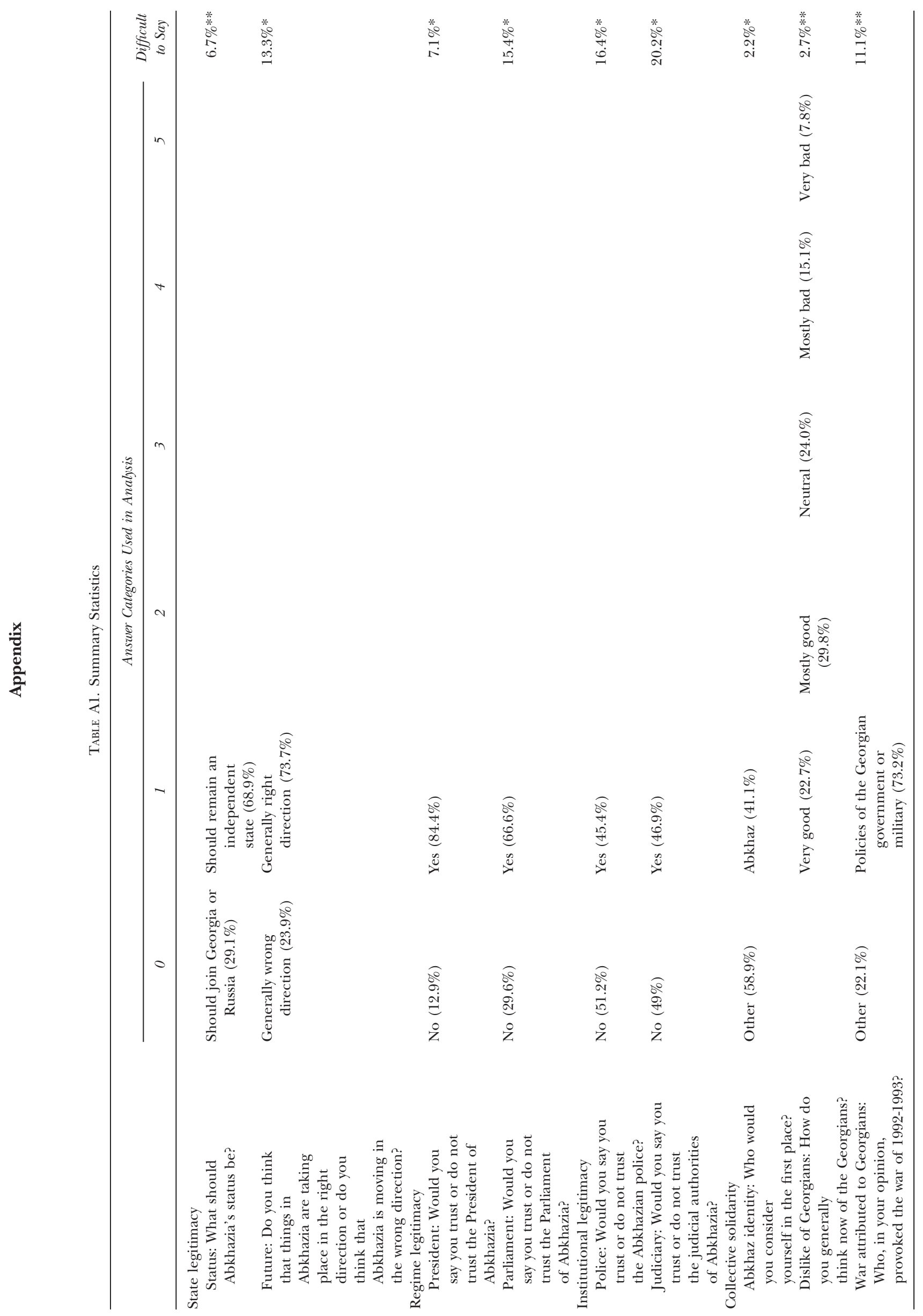




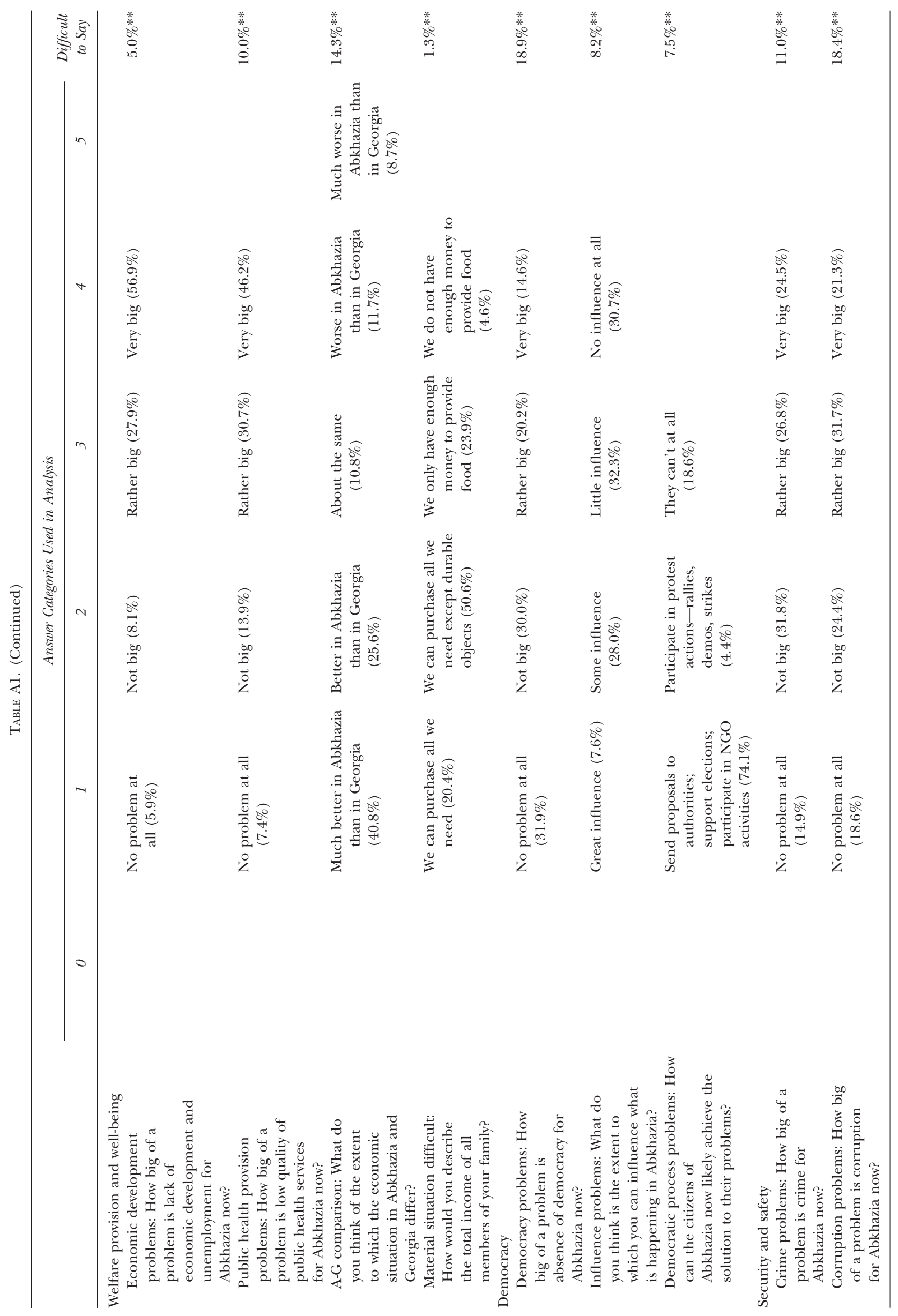


Kristin M. BAKKe ET AL.



